\title{
AKSES TANAH DAN KENDALA LEGITIMASI EKS-PENGUNGSI TIMOR TIMUR DI KABUPATEN BELU
}

\author{
Farid Abud Alkatiri \\ Departemen Sosiologi Fakultas Ilmu Sosial dan Ilmu Politik \\ Universitas Indonesia \\ Email: faridabud@yahoo.com
}

\begin{abstract}
Land exclusion has been an issue for the majority of the former East Timorese in Belu regency. The resettlement was offered as one of the the government's programs. Unfortunately, the program has not provided sufficient land to be accessed due to legitimation of the social institution. As a consequence of land exclusion, there have been various land conflicts between the refugees and the landlords. This aim of this research is to investigate the land exclusion issue caused by the power of legitimation. Some previous studies have been conducted to understand the problem, using conflict and public policy approaches to see why the issue has been occurring since 1999. Meanwhile, this article analyzes the legitimation of social institution and the roles of certain local figures in shaping land exclusion. To analyze the issue, this research uses social exclusion theory, specifically powers of exclusion, where legitimation as one of the essential issues. This research uses qualitative method, and the data is collected through in-depth interviews and secondary sources. The result of the research shows that majority refugees have faced difficulties to access to the land due to the legitimation of traditional institution (lembaga adat) and the role of local community leaders.
\end{abstract}

Keywords: Exclusion; Land; Legitimation; Resettlement; Traditional institution.

\begin{abstract}
ABSTRAK
Akses tanah menjadi satu persoalan bagi mayoritas eks-pengungsi Timor Timur di kabupaten Belu. Program resettlement merupakan salah satu program pemerintah. Akan tetapi, program tersebut ternyata tidak menyediakan akses tanah yang cukup. Konsekuensi dari eksklusi tanah tersebut, muncul berbagai konflik perebutan tanah antara pengungsi dan pemilik lahan. Tujuan dari penelitian ini adalah menginvestigasi bentuk-bentuk eksklusi tanah karena adanya kekuatan legitimasi. Beberapa studi sebelumnya dilakukan untuk memahami persoalan tersebut, menggunakan pendekatan konflik dan kebijakan publik untuk melihat mengapa persoalan masih terus terjadi sejak 1999. Sementara itu, penelitian ini menganalisa legitimasi institusi sosial dan peran para tokoh tertentu dalam membentuk eksklusi tanah. Untuk menganalisa persoalan tersebut, penelitian ini menggunakan teori eksklusi sosial, khusus powers of exclusion, di mana legitimasi merupakan salah satu isu esensial. Metode yang digunakan dalam penelitian ini adalah penelitian kualitatif, dan data diperoleh melalui wawancara mendalam dan data sekunder. Data penelitian menunjukkan mayoritas pengungsi Timor Timur menghadapi persoalan akses tanah karena adanya kekuatan legitimasi lembaga adat dan adanya peran tokoh lokal.
\end{abstract}

Kata Kunci: Eksklusi; Legitimasi; Lembaga adat; Resettlement; Tanah. 


\section{PENGANTAR}

Eksodus sebagian penduduk bekas provinsi Timor Timur pada tahun 1999 ke wilayah kabupaten Belu, menyisakan berbagai persoalan sosial di wilayah tersebut. Dari Laporan US Committee for Refugees and Immigrant (2000) jumlah pengungsi pada tahun 1999 mencapai kurang lebih 250.000 jiwa, dan telah berkurang menjadi 132.000 jiwa diseluruh wilayah Indonesia karena adanya program repatriasi, dan terus berkurang melalui program tersebut. Achmad (2000) menunjukkan data yang dilansir oleh Kementrian Kesejahteraan Sosial bahwa pengungsi di kabupaten Belu pada tahun 1999 mencapai 27.120 KK (KK singkatan dari Kepala Keluarga) atau sekitar 135.689jiwa. Akan tetapi, Kementerian Perumahan Rakyat Republik Indonesia tahun 2014 menunjukkan bahwa jumlah eks- pengungsi yang menetap di Belu saat ini berjumlah kurang lebih 16.000an KK atau diperkirakan sekitar 80.000 sampai dengan 100.000 jiwa.

Menurut Achmad (2000) jumlah pengungsi diluar dari perkiraan pemerintah provinsi NTT, sehingga berdampak pada penanganan pengungsi diberbagai kamp-kamp pengungsian. Secara umum, Kuswardono (2014: 3), terdapat empat persoalan utama yang dihadapi oleh pengungsian, yaitu ketiadaan akses terhadap pelayanan dasar, perumahan, akses tanah, dan lapangan pekerjaan.

Dengan jumlah pengungsi yang masih signifikan, maka potensi konflik di kampkamp pengungsi di Belu dapat terjadi setiap saat. Oleh karena itu, pemerintah daerah dan lembaga donor, serta Kodim 1605 Belu, melaksanakan pembangunan resettlement dan memobilisasi sebagian eks- pengungsi keluar dari kamp-kamp pengungsian. Selain itu, ada sebagian kecil eks-pengungsi memiliki inisiatif untuk pindah dari camp pengungsian secara individu atau kelompok, atau self-independent resettlement.

Salah satu modal bagi pengungsi untuk keluar dari kamp-kamp pengungsian adalah akses tanah, yang selama ini menjadi isu fundamental bagi sebagian besar eks-pengungsi yang masih menetap di kamp pengungsian maupun yang telah menempati resettlement- resettlement pengungsian. Persoalan eksklusi dan keterabatasan akses tanah berpotensi menimbulkan konflik sosial antara mereka dan penduduk lokal atau pemilik lahan. Sampai dengan tahun 2017, masih banyak eks-pengungsi yang menghadapi persoalan legitimasi mereka atas lahan resettlement yang ditempati, sehingga berdampak pada kegiatan pertanian mereka. Bahkan, sebagian eks-pengungsi harus terus bergantung pada kerjasama atau belas kasihan penduduk dan suku lokal sebagai pemilik lahan.

Telah dijelaskan bahwa suku lokal merupakan pemilik lahan terluas di kabupaten Belu. Dalam suku lokal tersebut, lembaga adat memegang peranan penting dalam menegakkan aturan dan memproteksi lahan suku masing-masing. Beberapa persoalan antara eks-pengungsi dengan suku lokal sering dijumpai, karena kuatnya pengaruh lembaga adat dan mekanisme proteksi lahan untuk kepentingan anggota suku. Umumnya, lembaga adat dapat menentukan pihak luar mana saja yang dapat mengakses lahan suku lokal, bahkan membatasi, menghalangi atau melakukan pengusiran terhadap keberadaan pihak luar di wilayah-wilayah kekuasaannya, seperti yang terjadi pada kelompok ekspengungsi Timor Timur di lahan milik suku Matabesi dan Liudasik di kabupaten Belu.

Untuk itu, persoalan utama yang diamati, yaitu peran dan proses lembaga adat dan aktor lokal dalam menggunakan legitimasinya sehingga tidak ada yang menghambat akses tanah komunitas bagi eks-pengungsi Timor Timur di Belu.

Tujuan Penelitian ini adalah menganalisa proses terjadinya eksklusi tanah komunitas eks-pengungsi yang dilakukan oleh lembaga adat dan aktor lokal dengan menggunakan perspektif legitimasi yang dikemukakan oleh Hall (2013), termasuk melihat implikasi yang dihadapi oleh komunitas eks-pengungsi akibat kebijakan resettlement pemerintah dan legitimasi lembaga adat. Sedangkan manfaat penelitian adalah memberikan kontribusi teoritis terhadap perspektif eksklusi tanah, dan juga menjelaskan isu akses tanah kelompok eks-pengungsi Timor Timur yang telah 
berlangsung sejak kedatangan mereka pada tahun 1999 di Belu.

Unruh dan Williams (2013:1) dan Rodgers (1995: 47) mengingatkan tereksklusinya seseorang atau kelompok dalam mendapatkan akses terhadap sumber daya, seperti tanah, justru menimbulkan konflik sosial antara berbagai pihak. Kemudian, Rodgers, 1995: 45; Figueroa, 1999: 6; Somerville, 2000: 145; Giddens, 2001: 323; dan Farrington, 2002; mengatakan bahwa tanah merupakan aset ekonomis terpenting agar manusia dapat hidup dan beraktivitas. Pentingnya akses tanah juga dikemukan oleh Lang (2005: 133) yang melihat tanah merupakan natural capital merupakan aset fundamental, bukan hanya sebagai kekayaan, tetapi kesehatan serta kunci bagi pekerjaan, kesejahteraan, dan ruang public juga.

Beberapa studi sebelumnya telah mengkaji persoalan akses tanah dan kebijakan resettlement di Belu. Misalnya, hasil studi Messakh (2003), berpendapat bahwa sulitnya akses tanah oleh ekspengungsi disebabkan oleh keterbatasan tanah. Pemerintah daerah tidak memiliki cukup lahan untuk membangun resettlement bagi pengungsi. Konsekuensi dari keterbatasan tanah tersebut berimplikasi terhadap peningkatan ekonomi keluarga, kemiskinan, buruknya tingkat kesehatan, dan rendahnya nutrisi makanan.

Studi lainnya juga dilakukan oleh Rame (2004) danSianipar (2016) yang meneliti dampak dari kebijakan resettlement di Belu. Menurut Rame, kebijakan resettlement tidak dilaksanakan optimal karena berbagai keterbatasan, seperti koordinasi pada level pemerintahan daerah, kondisi sosial dan ekonomi ekspengungsi yang tidak kondusif dan sejahtera serta ketidakjelasan implementasi program pemerintah. Sedangkan Sianipar melihat berbagai persoalan dari program resettlement, antara lain konflik sosial akibat ketidakjelasan status tanah, persyaratan pembangunan rumah yang memberatkan pengungsi, dan intimidasi penduduk lokal. Selain itu, keterbatasan data dan monitorisasi proyek pembangunan rumah yang tidak berjalan, turut memperburuk program resettlement, dan berdampak pada kehidupan pengungsi Timor Timur.
Pada hasil studi-studi sebelumnya di atas, umumnya persoalan akses tanah disebabkan oleh dua persoalan utama, yang sering menjadi perdebatan dalam isu pengungsi dan akses tanah, yaitu ketidakjelasan kebijakan pemerintah atau konflik sosial antara penduduk lokal dan ekspengungsi. Akan tetapi, penelitian ini melihat bahwa persoalan tanah di Belu disebabkan juga oleh adanya kekuatan lain, yaitu dominasi institusi sosial seperti lembaga adat dan peran aktor atau tokoh lokal.

Untuk menganalisa persoalan tersebut, maka penelitian ini menggunakan perspektif yang dikemukakan oleh Hall (2013), yaitu powers of exclusion. Dalam perspektif tersebut, Hall menjelaskan bahwa persoalan akses tanah dapat disebabkan oleh adanya kekuatan legitimasi yang dimiliki oleh aktor dalam memanfaatkan tanah dan mengeksklusi pihak lemah lainnya.

Hall (2013: 18) mengatakan bahwa legitimasi merupakan suatu bentuk justifikasi terhadap penggunaan lahan, dan sekaligus menjadi basis dari nilai-nilai moral terkait dengan penggunaan atau pemanfaatan tanah. Dalam penerapannya, legitimasi hadir untuk mendukung argumentasi-argumentasi yang mengatasnamakan pembangunan, keberadaban, modernitas, dan ekologis yang dikemukakan oleh aktor-aktor pelaku eksklusi tanah, baik itu state institutions atau non-state actors.

Disamping itu, legitimasi juga berkaitan dengan pola relasi dalam komunitas dan institusi lainnya, termasuk institusi adat, yang berkuasa dalam masyarakat. Lebih lanjut, Hall (2013: 2) menjelaskan bahwa aspek legitimasi juga memiliki ikatan yang kuat dengan aspek pasar atau land price, yang dijelaskan oleh Hall sebagai the determinant aspect of land exclusion. Selain letak tanah yang strategis, harga tanah mengalami peningkatan akibat adanya komoditas pertanian, yang memberikan peluang bagi perusahaan-perusahaan besar untuk menguasai tanah dan melakukan ekspansi bisnis.

Kemudian, kekuatan legitimasi dan pasar merefleksikan suatu proses yang terus berlangsung setiap harinya atau everyday processes 
dalam konteks intimate exclusion, di mana ada proses eksklusi yang terus terjadi antara aktor yang lebih kuat dengan pihak yang lemah.

Selain mendapatkan dukungan dari power of market, legitimasi juga regulasi dan kekerasan juga turut berperan dalam pembentukkan eksklusi tanah. Para aktor memanfaatkan legitimasi mereka untuk menetapkan aturan-aturan yang mendukung kepentingan mereka, bahkan mereka menggunakan institusi keamanan untuk menindak segala rintangan agar mencapai kepentingan tertentu. menggunakan perspektif powers of exclusion, penelitian ini menganalisa persoalan akses tanah dengan menggunakan paradigma monopoli dalam perspektif eksklusi sosial yang dikemukakan oleh Silver (1994). Dalam paradigma monopoli, isu social closure menjadi salah satu persoalan sentral, yang dideskripsikan oleh Max Weber sebagai suatu proses subordinasi, dimana kelompok tertentu memonopoli dan mendapatkan keuntungan dengan menghalangi kesempatan atau peluang pihak lain. Status kelompok merupakan manifestasi dari power relations dan mereka memiliki kesadaran, pola-pola konsumsi dan gaya hidup. Kemudian, materi, hukum, dan berbagai bentuk monopoli memperkuat status eksklusivitas kelompok penguasa. Selain itu, social closure terjadi ketika institusi dan budaya menjadi constraining aspect serta menciptakan inequality dalam masyarakat (Shanmugaratnam, 2004:9), konsekuensinya adalah terciptanya dominasi kelas sosial (Silver, 1994).

Penelitian ini dilakukan dengan menggunakan metode kualitatif dengan jenis penelitian studi kasus. Studi kasus dipilih karena melihat keunikan persoalan dan keberadaan komunitas secara geografis di kawasan perbatasan. Penelitian tentang eksklusi sosial dan akses tanah komunitas eks-pengungsi Timor Timur ini merupakan jenis studi kasus instrinsic case study, yaitu untuk memahami secara detail tentang proses terjadinya esklusi tanah dalam kehidupan eks-pengungsi di Kabupaten Belu.

Data dikumpulkan melalui in-depth interview dan secondary data. Penelitian dilakukan di tiga lokasi, yaitu resettlement Taeksoruk, wilayah adat suku Matabesi, dan beberapa resettlement di desa Silawan yang terletak di kawasan perbatasan Indonesia dengan TimorLeste. Penelitan dimulai pada bulan November 2016 sampai dengan Februari 2017. Wawancara dilakukan terhadap 18 informan, dari berbagai kalangan, yaitu eks-pengungsi, penduduk lokal, ketua adat, dan otoritas lokal, yang tersebar di resettlement Taeksoruk, kawasan suku Matabesi, dan desa Silawan.

\section{PEMBAHASAN \\ Konsep Legitimasi dalam Akses Atas Tanah}

Menurut Hall (2013), kekuatan legitimasi merupakan salah satu bentuk powers of exclusion, yang ditemui dibeberapa negara di Asia Tenggara, berbasiskan pada argumentasi atas pemanfaatan lahan dan membentuk serta mengikat relasi sosial dengan mengatasnamakan kepentingan institusi, kelompok, atau individu tertentu.

\section{Legitimasi Lembaga Adat dan Eksklusi Atas Tanah}

Dalam konteks persoalan akses atas tanah di Belu, aspek bagaimana lembaga adat menggunakan kekuatan legitimasi dalam memproteksi tanah suku, dan menghalangi pihak lain yang berupaya memiliki tanah suku tersebut. Legitimasi lembaga adat tidak terlepas dari dukungan power of regulation, yaitu peraturan perundangan-undangan yang berlaku. Dalam UUD 1945, masyarakat dan hukum adat diakui oleh UUD 1945 Pasal 18B ayat 2, Pasal 28I Ayat 3, dan Pasal 32 Ayat 1 dan 2. Kemudian, dalam Undang Undang Nomor 5 Tahun 1960 tentang Peraturan Dasar Pokok Pokok Agraria, juga mengatur tentang hak-hak masyarakat adat, khususnya yang berkaitan dengan hutan atau tanah adat, lebih dikenal dengan istilah hak ulayat.

Istilah tanah ulayat ditetapkan dalam Peraturan Menteri Negara Agraria/Kepala Badan Pertanahan Nasional Nomor 5 Tahun 1999 Tentang Pedoman Penyelesaian Masalah Hak Ulayat Masyarakat Hukum Adat Pasal 1. Dalam aturan ini, tanah ulayat dilihat sebagai 
tanah yang diatasnya terdapat hak ulayat dari suatu masyarakat adat tertentu. Sedangkan masyarakat hukum adat adalah sekelompok orang yang terikat oleh tatanan hukum dan memiliki kesamaan tempat tinggal.

Dengan diakuinya tanah ulayat dalam beberapa peraturan perundang-undangan di atas, maka lembaga adat sebagai salah satu social institution memiliki legitimasi untuk mengatur, memproteksi tanah adat, dan mempertahankan hutan adat dan tanah suku untuk kepentingan serta kelestarian adat istiadat.

Kondisi tersebut dapat dilihat pada suku Matabesi yang mendapatkan dukungan dari pemerintah daerah Belu melalui Peraturan Bupati Nomor 06 Tahun 2011 Tentang Tata Ruang Kawasan, di mana kawasan hutan adat Matabesi dijadikan sebagai salah satu wilayah konservasi pariwisata dan budaya. Dukungan regulasi tersebut memperkuat posisi lembaga adat Matabesi untuk memproteksi kawasan hutan adat Matabesi dari pihak manapun yang mencoba mengakses atau memiliki lahan di sekitar kawasan tersebut. Misalnya, lembaga adat Matabesi juga pernah melakukan pembatalan akses tanah adat terhadap Dinas Kehutanan Kabupaten Belu, yang menganggap kawasan hutan Matabesi sebagai bagian dari wilayah hutan milik negara. Akan tetapi, klaim tersebut dibantah oleh ketua suku adat Matabesi dengan melakukan perlawanan dan membatalkan klaim dari pemerintah daerah tersebut.

Bahkan, menurut ketua adat tersebut bahwa lembaga adat Matabesi memiliki legitimasi untuk membatasi pihak manapun, baik itu anggota suku maupun pembeli untuk melakukan transaksi jual beli tanah adat maupun kawasan penyanggah tanah adat Matabesi.

Akan tetapi, pola pikir ketua adat tersebut dilihat telah melampaui wewenangnya karena telah menggunakan kekuasaannya menghalangi pihak lain memiliki tanah diwilayah penyanggah kawasan hutan pariwisata dan budaya, yang letaknya di luar dari kawasan hutan tersebut. Misalnya, lembaga adat Matabesi mampu membatalkan transaksi jual beli lahan seluas kurang lebih empat hektar antara pemilik lahan pribadi dengan beberapa tokoh eks-pengungsi Timor Timur untuk kepentingan pembangunan resettlement eks-pengungsi. Alasannya adalah letak tanah tersebut berada di sekitar wilayah penyanggah hutan Matabesi yang akan dijadikan sebagai kawasan hutan pariwisata.

Berbagai persoalan pembatalan dan penghalangan tersebut terjadi karena lembaga adat suku Matabesi merasa memiliki legitimasi untuk melakukan pembatalan proses transaksi tanah di sekitar kawasan penyanggah hutan adat Matabesi. Lembaga adat Matabesi hanya mengakui segala transaksi jual beli tanah yang telah berlangsung sebelum peraturan daerah tersebut diberlakukan.

Bagi pihak yang tidak menuruti peraturan adat tersebut, berpotensi mengalami berbagai kesulitan pengurusan proses jual beli dan sertifikasi tanah dan berbagai sanksi sosial dan kultural. Artinya bahwa pihak adat, tokoh masyarakat, atau pejabat kelurahan tidak "berani" melanjutkan atau mengizinkan proses transaksi jual beli dan sertifikasi tanah. Pihak kelurahan tidak berani menindaklanjuti segala urusan tersebut karena tidak ingin menghadapi kekuatan lembaga adat Matabesi.

Dari hasil observasi penelitian ini, sebagian pejabat otoritas kelurahan merupakan anggota suku Matabesi, sehingga mereka lebih patuh pada aturan budaya lokal. Bagi pelanggar aturan tersebut, dikenakan sanksi budaya dan sosial. Lembaga adat dapat bertindak keras terhadap segala pelaku transaksi tersebut. Bahkan hukum formal tidak menjadi prioritas penyelesaian karena kekuatiran pihak yang bertransaksi menghadapi lembaga adat dan anggota suku. Dengan demikian, maka pihak pemilik tanah dan para tokoh eks-pengungsi memutuskan untuk tidak melanjutkan transaksi tersebut.

Dalam konteks ini, legitimasi lembaga adat didukung oleh kekuatan hukum formal (regulation) dan kekerasan (force) untuk memproteksi tanah adat, bahkan telah melampaui batas dengan membatalkan transaksi jual beli di sekitar daerah penyanggah.

Kuatnya pengaruh lembaga adat juga masih dapat dilihat di desa Silawan. Lembaga 
adat memiliki legitimasi untuk menentukan lahan mana yang dapat dan tidak dapat diakses oleh pemerintah, penduduk lokal maupun ekspengungsi. Seperti yang dijelaskan oleh ketua lembaga adat Silawan bahwa dirinya pernah menemui pihak pengembang proyek PLBN Motaain (Pos Lintas Batas Nasional Mota'ain) untuk merubah desain gambar jalur jalan raya perbatasan tersebut agar tidak melalui hutan adat Sarobon, yang dipercaya sebagai tempat munculnya nenek moyang orang Silawan, yaitu Mane Ki'ik. Akhirnya, pemerintah dan perusahaan menyetujui untuk mengubah desain jalur proyek jalan tersebut mengikuti keinginan lembaga adat desa Silawan.

Sebagai $N a^{\prime} i$ atau ketua adat Silawan, ketua lembaga adat Silawan memiliki otoritas penuh untuk melarang atau mengizinkan pembangunan atau akses tanah di sekitar wilayah desa Silawan. Ketua adat Silawan dengan tegas mengatakan bahwa tanah adat di Silawan dilarang untuk diberikan kepada eks-pengungsi. Hal tersebut dibuktikan dengan dibatalkannya transaksi jual beli antara mantan kepala desa Silawan dengan salah satu tokoh eks-pengungsi Timor Timur, yang berkeinginan membeli tanah adat yang terletak di kawasan PLBN Mota'ain dan Hutan adat Sarobon. Tanah adat tersebut merupakan tanah sejarah bagi masyarakat lokal karena dipercaya sebagai "pintu" masuknya agama Katholik melalui jalur laut ke wilayah desa Silawan, dan menyebar ke seluruh pulau Timor, atau dalam istilah lokal Silawan disebut Kanokar Bo'ot dan Kanokar Ki'ik.

Bahkan, ketua lembaga adat Silawan mengancam akan bertindak tegas apabila transaksi tersebut dilanjutkan. Bagi lembaga adat Silawan, mempertahankan hutan adat dan nilai dan norma lokal atau feharalan adalah prioritas utama, sekaligus mengukuhkan desa Silawan sebagai desa adat di kawasan perbatasan antarnegara tersebut.

Selain itu, persoalan legitimasi lembaga adat dan akses tanah juga ditemui di lokasi resettlement lainnya, yaitu resettlement Taeksoruk di desa Fatuba'a. lahan resettlement tersebut merupakan pemberian sementara suku Lidausik kepada pemerintah daerah
Belu pada tahun 2000, yang digunakan untuk kepentingan pengungsi selama tiga tahun. Akan tetapi, sampai tahun 2017, resettlement tersebut masih ditempati oleh eks- pengungsi Timor Timur. Persoalan utama adalah status lahan tersebut memang tetap menjadi milik suku Liudasik, tetapi kelompok eks- pengungsi juga melakukan klaim bahwa lahan tersebut menjadi milik mereka sebagai bagian dari program transmigrasi lokal yang telah ditempati selama 17 tahun. Berbagai mekanisme ditempuh oleh kelompok eks- pengungsi untuk dapat memiliki tanah tersebut, termasuk melalui pendekatan politis dan kultural.

Pendekatan politis dilakukan bertepatan dengan pemilihan kepala desa Fatuba'a pada tahun 2016 bahwa salah satu anggota suku Liudasik menjadi kandidat kepala desa. Kedua pihak saling melakukan pendekatan sehingga tercapailah kesepatakan bahwa semua suara kelompok masyarakat eks-pengungsi Timor Timur dimobilisasi untuk pemenangan kandidat yang berasal dari suku lokal tersebut. Sebaliknya, apabila kandidat tersebut terpilih, maka persoalan status tanah dituntaskan melalui mekanisme land titling atau pengakuan kepemilikan tanah untuk eks-pengungsi Timor Timur. Walaupun kelompok eks- pengungsi menjadi "komoditas" politik, peluang tersebut dimanfaatkan oleh mereka untuk menperjelas status dan kepemilikan tanah resettlement Taeksoruk yang telah ditempati tersebut.

Hasil perhitungan suara menunjukkan kemenangan kandidat suku Liudasik, terutama di lokasi TPS eks-pengungsi. Hasil tersebut menjadikan kandidat suku lokal tersebut unggul tujuh suara dari kandidat lainnya. Dengan demikian, kepala desa terpilih memenangkan pemilihan desa berkat dukungan kelompok eks-pengungsi Timor Timur.

Kemenangan tersebut diakui oleh kepala desa terpilih dan keluarganya bahwa kemenangan tersebut ditentukan oleh kelompok eks-Timor Timur sebagai relasi reprositas antara mereka dengan kelompok pengungsi yang berbasis pada solidaritas dan kohesivitas kedua kelompok. Kesepakatan politis tersebut dikonfirmasikan kepada kepala desa terpilih, 
tetapi kepala desa tersebut menolak bahwa kemenangan tersebut bukan atas dasar barter kepentingan antara kekuasaan dan status tanah. Bahkan, kepala desa terpilih tidak menjamin akan meninjau ulang atau menyelesaikan status tanah melalui transfer kepemilikan kepada kelompok eks-pengungsi.

Dalam pandangan kepala desa terpilih, keputusan tidak dapat mengambil keputusan sendiri karena lahan tersebut adalah milik suku Liudasik, dan tidak dapat diserahkan kepada kelompok eks-pengungsi. Apabila ada penyerahan atau transfer kepemilikan tanah, maka harus melalui mekanisme adat atau sering disebut sirih-pinang, yaitu adanya proses ganti rugi secara kekeluargaan. Dengan tidak adanya kejelasan penyelesaian dan tidak dipenuhinya kesepakatan tersebut, maka salah satu kordinator senior eks- pengungsi Timor Timur yang merupakan anggota DPRD Belu menyarankan agar lahan resettlement tersebut dibeli untuk menghindari persoalan di masa mendatang. Konteks terus menunjukkan bahwa eks- pengungsi merupakan kelompok yang rentan dengan berbagai bentuk persoalan dan manipulasi.

Untuk menghindari penggusuran dan persoalan sosial lainnya, kelompok ekspengungsi melakukan pendekatan kultural terhadap suku Liudasik. Hasilnya, kelompok eks-pengungsi diterima sebagai anggota suku Liudasik melalui mekanisme sumpah adat. Bagi eks-pengungsi di resettlement Taeksoruk, pendekatan ini diyakini sebagai "pengikat" di antara mereka dengan suku lokal tersebut. Umumnya, pendekatan budaya seperti ini mampu mengikat dan mempererat pihak-pihak terkait yang memiliki kesamaan latarbelakang etnis dan juga disertai dengan adanya sanksi atau norma budaya bagi pelanggarnya. Dalam pandangan eks-pengungsi Taeksoruk, pendekatan kultural ini dapat menjadi jaminan bahwa mereka tidak akan digusur oleh suku Liudasik. Sebaliknya, pendekatan kultural ini dianggap dapat memberikan peluang kepada eks-pengungsi untuk memiliki tanah resettlement tersebut.

Akan tetapi, kesepakatan antara kedua belah pihak pada periode pemilihan kepala desa tersebut hanyalah kesepakatan lisan, sehingga tidak memiliki kekuatan hukum. Bahkan, sumpah adat pun tidak menjadi jaminan bagi eks-pengungsi untuk menuntut kepemilikan tanah resettlement. Sejak pelantikan kepala desa Fatuba'a pada Oktober 2016 sampai saat ini, perjanjian tersebut belum dapat direalisasikan karena terbentur dengan legitimasi lembaga adat dan kepentingan anggota suku Lidausik.

\section{Legitimasi Aktor Lokal dan Akses Atas Program Bantuan Perumahan}

Hasil penelitian ini juga menunjukkan bahwa eksklusi sosial yang disebabkan oleh kekuatan legitimasi yang melekat pada individu-individu atau tokoh-tokoh lokal dan eks-pengungsi yang menggunakan institusi-institusi sosial sebagai instrumen dalam mencapai kepentingan tertentu. Misalnya, pembatasan posisi penting dalam masyarakat desa Silawan. Para eks-pengungsi tidak diberikan izin untuk mencalonkan diri menjadi kepala dusun atau posisi yang lebih tinggi dalam struktur pemerintahan desa. Mengacu pada aturan yan disepakati, pejabat pemerintahan desa, kepala desa, dan kepala dusun harus berasal dari orang asli Silawan.

Kepala desa dan beberapa tokoh masyarakat membenarkan bahwa posisi kepala dusun harus dijabat oleh orang lokal, bukan "pendatang", khsususnya eks- pengungsi Timor Timur.

Berbagai alasan disampaikan oleh para tokoh lokal. Pertama, adanya kekuatiran terhadap tergerusnya eksistensi nilai dan norma lokal Silawan. Menurut kepala desa dan ketua adat Silawan, jabatan kepala dusun memang tidak boleh diserahkan kepada "orang luar", walaupun diakui bahwa relasi sosial antara penduduk lokal dengan eks-pengungsi terjalin baik karena adanya kesamaan nilai budaya secara umum. Kedua, komunitas eksTimor Timur belum dapat dipercaya untuk menjabat kepala dusun karena dianggap belum berkompeten dan cenderung tidak berpegang pada nilai dan norma budaya lokal, atau nilai fehalaran. Ketiga, beberapa tokoh masyarakat Silawan merisaukan kehadiran eks-pengungsi di Silawan, yang masih cenderung dianggap 
"keras kepala", tidak patuh pada aturan atau perintah otoritas lokal Silawan. Para tokoh lokal melihat bahwa sikap eks- pengungsi Timor Timur yang dinilai tidak mudah untuk "diperintah" oleh otoritas lokal. Menurut para tokoh lokal, sikap dan perilaku komunitas eksTimor Timur yang "keras kepala" dan susah diatur membuat tokoh-tokoh masyarakat Silawan kuatir akan terjadinya konflik atau berpengaruh terhadap pola pikir masyarakat lokal.

Dengan tiga alasan utama tersebut, maka otoritas dan tokoh lokal memandang perlu adanya pembatasan penempatan ekspengungsi dalam penyelenggaraan pemerintahan desa Silawan. Jabatan ditingkat masyarakat yang layak dijabat oleh tokoh atau individu komunitas eks- pengungsi adalah ketua RT atau RW, walaupun eks-pengungsi telah membentuk dusun Halimuti dan menjadi mayoritas di dusun tersebut.

Pembatasan jabatan pada tingkat dusun dan struktur pemerintahan desa sangat berdampak pada penentuan keputusan yang berkaitan dengan akses terhadap tanah dan bantuan sosial, seperti program perumahan RISHA di desa Silawan.

Dengan melekatnya legitimasi pada beberapa aktor sebagai tokoh masyarakat dan kepala dusun, maka ada kecenderungan bahwa segala keputusan yang dibuat lebih banyak menguntungkan pihak aktor dan orang-orang terdekat. Misalnya, akses terhadap bantuan tanah dan rumah yang merupakan satu paket dalam program rumah RISHA di desa Silawan, hanya diterima oleh anggota masyarakat tertentu dan memiliki kedekatan dengan 5 (lima) kepala dusun saja. Sedangkan, warga masyarakat dari 5 (lima) dusun lainnya tidak menerima bantuan rumah tersebut, termasuk 9 (sembilan) KK eks-pengungsi Timor Timur yang masih menempati kamp-pengungsian di Dusun Aisik. Pejabat otoritas lokal Silawan menjelaskan beberapa alasan mengapa kelima dusun tersebut tidak menerima bantuan rumah RISHA, antara lain jarak lima dusun lainnya jauh dari lokasi rumah RISHA, mata pencaharian yang berbeda, dan tidak memenuhi syarat penerima bantuan rumah RISHA seperti status rumah tangga.

Berdasarkan pada hasil observasi, jarak antara 5 (lima) dusun lainnya dengan lokasi rumah RISHA tidaklah jauh, bahkan anggota masyarakat atau 99 KK eks-pengungsi menyatakan kesediaannya menempati rumah RISHA, tetapi keinginan mereka tidak terpenuhi. Kemudian, isu tentang perbedaan mata pencaharian merupakan argumentasi yang tidak tepat karena mayoritas penduduk Silawan memiliki matapencaharian yang homogen yaitu petani. Sedangkan persyaratan lain yang ditentukan oleh otoritas lokal adalah seperti status rumah tangga, seperti lansia dan keluarga baru merupakan alasan yang dianggap tidak representatif dalam pendistribusian rumah RISHA tersebut.

Padahal, persyaratan untuk mendapatkan rumah RISHA tidak terkait dengan kriteria yang disepakati oleh kepala desa dan tokohtokoh tertentu karena tujuan utama dari program bantuan perumahan dari pemerintah pusat tersebut tersebut diperuntukkan bagi masyarakat berpenghasilan rendah secara umum.

Konsekuensi dari ketidakadilan pendistribusian bantuan perumahan tersebut, maka muncul berbagai spekulasi dan pandangan terhadap kepala desa dan beberapa kepala dusun yang mendapatkan kesempatan tersebut. Beberapa tokoh lokal lainnya desa Silawan mengindikasikan bahwa perbedaan penanganan atau pendistribusian bantuan tersebut disebabkan oleh perbedaan pilihan politik dalam kontestasi pemilihan kepala desa lalu. Pejabat utama desa Silawan dinilai memprioritaskan anggota masyarakat tertentu yang telah memilihnya menjadi pejabat otoritas lokal pada pemilihan ditingkat desa.

Pandangan tersebut juga dibenarkan oleh beberapa anggota dari 9 (sembilan) KK eks-pengungsi di kamp-pengungsian Aisik mengatakan bahwa mereka tidak mendapatkan informasi atau ajakan dari pihak pemerintahan desa Silawan, padahal mereka berharap menjadi peserta penerima bantuan rumah RISHA. Para penghuni kamppengungsian tersebut yakin bahwa keputusan 
tersebut merupakan keputusan politis dan diskriminatif yang dilakukan oleh pihak-pihak yang memiliki akses terhadap keputusan di pemerintahan desa.

Kecurigaan para pengungsi di kamp-Aisik dan keterangan ketua adat Silawan tentang adanya penentuan kriteria penerima bantuan secara sepihak oleh tokoh-tokoh lokal akhirnya dibenarkan oleh pejabat otoritas desa Silawan dan beberapa kepala dusun yang terlibat dalam penentuan persyaratan dan keputusan penerima rumah RISHA. Kepala desa tersebut menjelaskan bahwa kriteria dan daftar peserta penerima bantuan perumahan RISHA diatur oleh tokoh lokal yang sebagiannya adalah kepala-kepala dusun di desa tersebut. Sebanyak 5 (lima) dari 10 kepala dusun yang ada didesa tersebut mendominasi penentuan peserta penerima bantuan rumah RISHA.

Dalam keterangannya, kepala desa Silawan menjelaskan bahwa sebenarnya dari 100 unit bantuan rumah RISHA, setiap dusun mengirimkan $10 \mathrm{KK}$, sehingga setiap mendapatkan jatah $10 \mathrm{KK}$. Akan tetapi prioritas hanya diberikan kepada 5 dusun saja, sedangkan 5 (lima) dusun lainnya merasa dieliminasi oleh pejabat pemerintahan desa tanpa ada penjelasan detail.

Dalam daftar penerima bantuan tersebut, sebagian merupakan anggota keluarga kepala dusun penentu keputusan atau pembuat daftar penerima bantuan tersebut. Proses ini berpotensi menyingkirkan anggota masyarakat lainnya yang sebenarnya dinilai lebih pantas menerima bantuan perumahan tersebut.

Hal tersebut diakui oleh salah satu kepala dusun penentu keputusan bahwa dirinya mendapatkan prioritas pengusulan nama peserta penerima bantuan rumah RISHA, dimana nama-nama penerima bantuan rumah RISHA terdapat anggota keluarganya.

Salah satu dusun yang tidak mendapatkan akses bantuan perumahan RISHA adalah dusun Beilaka. Berdasarkan keterangan dari kepala dusun Beilaka, proses penentuan keputusan peserta penerima bantuan perumahan RISHA memang cenderung diskriminatif, padahal bantuan perumahan tersebut diperuntukkan untuk semua dusun desa Silawan.
Konteks tersebut menunjukkan bahwa legitimasi dan kekuasaan yang dimiliki para tokoh lokal, mampu membatasi atau mengeksklusi para eks-pengungsi dan penduduk lokal dalam hal akses tanah, bantuan perumahan, dan pembatasan posisi penting dalam masyarakat. Walaupun menurut tokoh lokal bahwa pembatasan akses kekuasaan dan partisipasi eks-pengungsi secara sosial dan politis bertujuan untuk mempertahankan nilai-nilai budaya lokal dan stabilitas sosial. Akan tetapi, data lapangan menunjukkan bahwa pembatasan tersebut berkaitan dengan akses terhadap sumberdaya ekonomi, sosial, dan politik di desa Silawan, sehingga praktikpraktik diskriminatif ditempuh untuk membatasi akses eks- pengungsi diberbagai dimensi kehidupan.

Hasil penelitian juga ini menunjukkan bahwa social closure atau terjadinya subordinasi kelompok eks-pengungsi berlangsung karena adanya legitimasi dan relasi sosial yang timpang. Pada dasarnya, tidak ada kompetisi perebutan tanah antara lembaga adat dengan kelompok eks pengungsi Timor Timur karena beberapa aspek. Pertama, kekuatan dan dominasi lembaga adat atas kepemilikan tanah merupakan suatu bentuk ascribed status, dan dipertahankan oleh suku lokal. Kedua, mayoritas eks-pengungsi memang telah berada pada posisi sebagai kelompok inferior group sejak awal kedatangan mereka di Belu. Ketiga, terjadi pembiaran oleh pemerintah daerah Belu yang cenderung tidak membantu menyelesaikan persoalan status tanah resettlement yang sebelumnya dibangun oleh pemerintah daerah Belu.

\section{SIMPULAN}

Dalam Pandangan Hall (2013), legitimasi merupakan suatu bentuk justifikasi terhadap pemahaman tentang penggunaan lahan, dan sekaligus menjadi basis dari nilai-nilai moral. Di samping itu, legitimasi juga berkaitan dengan pola relasi dalam komunitas dan institusi lainnya, termasuk institusi adat, yang berkuasa dalam masyarakat.

Dalam kasus akses tanah di Belu, legitimasi menjadi kekuatan penentu, sebagai kontributor 
munculnya eksklusi tanah. Lembaga adat memiliki legitimasi dan pengaruh yang kuat dalam menentukan penggunaan lahan, termasuk melakukan proteksi atas hutan dan tanah adat dari akses atau gangguan pihak luar. Hal tersebut dilakukan oleh lembaga adat Matebesi, Taeksoruk, dan Silawan, yang membatalkan dan menentang penetrasi kapital dalam urusan akses tanah di Belu. Selain itu, legitimasi tokoh lokal turut memperburuk kondisi eksklusi tanah yang dihadapi oleh sebagian eks-pengungsi. Peran otoritas dan tokoh lokal, menempatkan eks-pengungsi terus berada pada kelompok sosial kelas bawah yang rentan praktik diskriminatif dan politis.

Dalam teori powers of exclusion yang dikemukakan oleh Hall (2013) legitimasi memiliki ikatan yang kuat dengan power of market dan mendapatkan dukungan dari powers of regulation dan force. Temuan penelitian menunjukkan adanya kaitan antara power of legitimation dengan power of market, khususnya keinginan suku Matabesi mengkomersialisasikan wilayah hutan adat menjadi kawasan pariwisata. Meskipun demikian, peran power of market melalui mekanisme land price yang dikemukakan oleh Hall ternyata berbeda dengan komersialisasi tanah adat versi suku Matabesi.

Dalam temuan Hall bahwa land price mengalami peningkatan akibat adanya peningkatan harga pada komoditas pertanian tertentu atau letak tanah di kawasan strategis. Dengan adanya peningkatan harga tanah, maka dengan sendirinya akan mengeksklusi dan menurunkan daya beli kelompk lemah atas tanah, sebaliknya memberikan peluang atau monopoli kepada pemodal besar. Akan tetapi, eksklusi tanah adat Matabesi dilakukan untuk memproteksi tanah adat dengan tujuan komersialisasi hutan adat demi kesejahteraan anggota suku, sehingga menimbulkan social closure dan eksklusi tanah bagi kelompok.

Sedangkan isu akses tanah di suku Taeksoruk dan Silawan, power of market tidak sepenuhnya mendukung power of legitimation. Fakta menunjukkan bahwa lembaga adat Liudasik dan Silawan murni ingin memproteksi kawasan hutan dan tanah adat sebagai tanah komunal anggota suku dan menjaga eksistensi nilai, norma, dan simbol budaya dilokasi masing-masing, bukan untuk tujuan komersial. Akan tetapi, terlihat jelas bahwa power of legitimation memerlukan dukungan power of regulation dan force dapat mempertahankan argumentasi dan justifikasi moral dalam rangka memproteksi tanah adat dan suku.

Kemudian, peran tokoh lokal tertentu turut memperburuk kondisi kehidupan ekspengungsi Timor Timur melalui pembatasan partisipasi dalam posisi strategis dalam masyarakat, yang berimplikasi terhadap akses dan bantuan sosial, khususnya program rumah RISHA.

\section{DAFTAR PUSTAKA}

Achmad, J. (2013). East Timorese Refugees in West Timor,dalam buku Destruction and Reconstruction of East Timor, editor James J. Fox dan Dionisio Babo Soares, edt. 2000. ANU Press, Canberra.

Farrington, F. (2002). Towards a Useful Definition: Advantages and Criticisms of 'Social Exclusion', Student of Flinders University, School of Geography, Population and Environmental Management. Adelaide: Flinders University.

Figueroa, A. (1999). Social Exclusion and Rural Underdevelopment, Paper prepared for the World Bank Conference on Evaluation and Poverty Reduction, Washington, D.C., June 14-15.

Giddens, A. (2001). Sociology, $4^{\text {th }}$ ed, Cambridge: Polity Press.

Hall, D, Hirsch, P, dan Li, TM. (2013). Powers of Exclusion: Land Dilemmas in Southeast Asia. Honolulu: University of Hawai'i Press.

Kuswardono, T. (2014). Penyediaan Lahan untuk Pemukiman Warga Baru di Kab. Kupang: Masalah, Tantangan dan Rekomendasi. Policy Paper No. 1/1/2014. Institute for Research and Empowerment (IRE). 
Lang, T.(2015). What Is Food and Farming Food?: the (re)emergence of health as a key policy for driver, Chapter 5, Part II: Global Development and Policy Question, Dalam Frederick H. Buttel and Philip McMichael. 2005. New Direction in the Sociology of Global Development, Research in Rural Sociology and Development, Volume II, Elsevier Lda, New York.

Messakh, T.A. (2003). Kebijakan Pemukiman Kembali Pengungsi di Perbatasan Indonesia-Timor Lesre: studi kasus Kecamatan Tasifeto Timur, Kabupaten Belu, Provinsi Nusa Tenggara Timur. Semarang: Tesis Program Pascasarjana, Studi Magister Perencanaan Pembangunan Wilayah dan Kota, Universitas Diponegoro.

Rodgers, G. (1995). What Is Special About a Social Exclusion Approach?, Chapter 2. Dalam Gerry Rodgers, Charles Gore, dan Jose B. Figueiredo, Social Exclusion: rhetoric, reality, and responses, 2005. International Institute for Labour Studies, Geneva, pp. $43-56$

Rame, F. (2004). Implementasi Kebijakan Resettelement Terhadap Warga Masyarakat Pengungsi Timor-Timur di Kabupaten Belu Provinsi Nusa Tenggara Timur. Yogyakarta: Master Tesis Ilmu Politik, Universitas Gadjah Mada.
Shanmugaratnam, N. (2003). Interpretations of Poverty: a critical review of dominant approaches, Centre for International Environment and Development Studies. Noragric: Agricultural University of Norway, 2004.

Sianipar, K.D. (2016). Resettlement of Former East Timorese Refugees in East Nusa Tenggara. Dalam Observing Policy Making in Indonesia, Erhard Friedberg and Mary E. Hilderbrand, Editor, Springer, Singapore, pp.79118.

Silver, H. (1994). Social Exclusion and Social Solidarity: three Paradigms, International Labour Review, Vol. 133, 1994/5-6, Discussion Papers.

Somerville, P. (2000). Social relations and social exclusion: rethinking political economy. London: Routledge.

Unruh, J. dan Williams, R.C. (2013). Land and Post-Conflict Peacebuilding, Policy Brief, No. 3, the Environmental Law Institute, London.

US Committee for Refugees and Immigrants. (2000). East Timorese Refugees in West Timor. Diakses dari <http:// www.refworld.org/cgi-bin/texis/ $\mathrm{vtx} /$ rwmain? page $=$ category\&categ ory $=$ COI\&publisher $=$ USCRI\&type $=$ \&coi=TMP\&docid=3b31e16118\&sk ip=0>, pada tanggal 17 Mei 2013. 